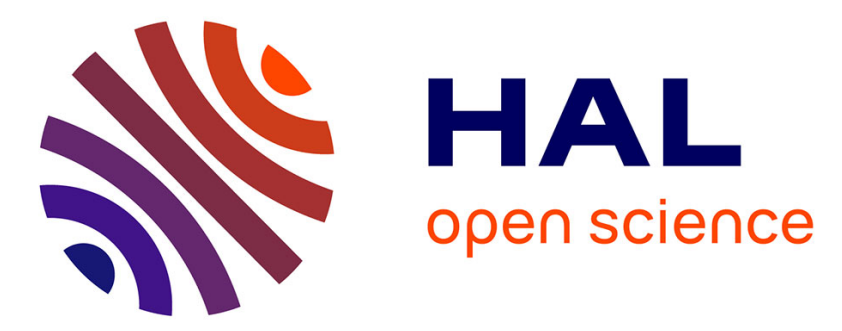

\title{
GLUT2 and the incretin receptors are involved in glucose-induced incretin secretion
}

\author{
Patrice D. Cani, Jens J. Holst, Daniel J. Drucker, Nathalie M. Delzenne, \\ Bernard Thorens, Rémy G. Burcelin, Claude Knauf
}

\section{To cite this version:}

Patrice D. Cani, Jens J. Holst, Daniel J. Drucker, Nathalie M. Delzenne, Bernard Thorens, et al.. GLUT2 and the incretin receptors are involved in glucose-induced incretin secretion. Molecular and Cellular Endocrinology, 2007, 276 (1-2), pp.18. 10.1016/j.mce.2007.06.003 . hal-00531937

\section{HAL Id: hal-00531937 https://hal.science/hal-00531937}

Submitted on 4 Nov 2010

HAL is a multi-disciplinary open access archive for the deposit and dissemination of scientific research documents, whether they are published or not. The documents may come from teaching and research institutions in France or abroad, or from public or private research centers.
L'archive ouverte pluridisciplinaire HAL, est destinée au dépôt et à la diffusion de documents scientifiques de niveau recherche, publiés ou non, émanant des établissements d'enseignement et de recherche français ou étrangers, des laboratoires publics ou privés. 


\section{Accepted Manuscript}

Title: GLUT2 and the incretin receptors are involved in glucose-induced incretin secretion

Authors: Patrice D. Cani, Jens J. Holst, Daniel J. Drucker, Nathalie M. Delzenne, Bernard Thorens, Rémy Burcelin, Claude Knauf

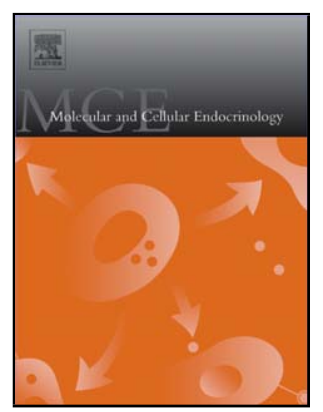

PII: S0303-7207(07)00235-3

DOI: doi:10.1016/j.mce.2007.06.003

Reference: MCE 6671

To appear in: $\quad$ Molecular and Cellular Endocrinology

Received date: 6-3-2007

Revised date: $\quad 12-4-2007$

Accepted date: $\quad$ 19-6-2007

Please cite this article as: Cani, P.D., Holst, J.J., Drucker, D.J., Delzenne, N.M., Thorens, B., Burcelin, R., Knauf, C., GLUT2 and the incretin receptors are involved in glucose-induced incretin secretion, Molecular and Cellular Endocrinology (2007), doi:10.1016/j.mce.2007.06.003

This is a PDF file of an unedited manuscript that has been accepted for publication. As a service to our customers we are providing this early version of the manuscript. The manuscript will undergo copyediting, typesetting, and review of the resulting proof before it is published in its final form. Please note that during the production process errors may be discovered which could affect the content, and all legal disclaimers that apply to the journal pertain. 
GLUT2 and the incretin receptors are involved in glucose-in duced incretin secretion

Patrice D. Cani ${ }^{1,5}$, Jens J. Holst ${ }^{3}$, Daniel J. Drucker ${ }^{4}$, Nathalie M. Delzenne ${ }^{5}$, Bernard Thorens $^{2}$, Rémy Burcelin ${ }^{1 *}$ and Claude Knauf ${ }^{1 *}$

1 Institut de Médecine Moléculaire de Rangueil, I²MR, IFR31, CHU Rangueil, BP 84225, 31432 Toulouse Cedex 4, France.

2 Institute of Pharmacology and Toxicology; University of Lausanne 27, rue du Bugnon, H1005 Lausanne, Switzerland.

3 Department of Medical Physiology, The Panum Institute; Copenhagen, Denmark.

4 Banting and Best Diabetes Centre, Department of Medicine, Mt. Sinai Hospital, University of Toronto, Canada.

5 Unit of Pharmacokinetics, Metabolism, Nutrition and Toxicology, Université catholique de Louvain, Av. E. Mounier, 73/69, 1200 Brussels., Brussels, Belgium

*Corresponding author:

Drs. Claude Knauf \& Rémy Burcelin

I²MR, IFR31, CHU Rangueil, BP 84225, 31432 Toulouse Cedex 4, France.

E-mail : claude.knauf@,toulouse.inserm.fr $\& \underline{\text { burcelin@,toulouse.inserm.fr }}$ 


\begin{abstract}
Glucagon-Like Peptide-1 (GLP-1) and Glucose-dependent Insulinotropic Polypeptide (GIP) are incretins secreted in response to oral glucose ingestion by intestinal L and $\mathrm{K}$ cells, respectively. The molecular mechanisms responsible for intestinal cell glucose sensing are unknown but could be related to those described for $\beta$-cells, brain and hepatoportal sensors. We determined the role of GLUT2, GLP-1 or GIP receptors in glucose-induced incretins secretion, in the corresponding knockout mice. GLP-1 secretion was reduced in all mutant mice, while GIP secretion did not require GLUT2. Intestinal GLP-1 content was reduced only in GIP and GLUT2 receptors knockout mice suggesting that this impairment could contribute to the phenotype. Intestinal GIP content was similar in all mice studied. Furthermore, the impaired incretins secretion was associated with a reduced glucose-stimulated insulin secretion and an impaired glucose tolerance in all mice. In conclusion, both incretin secretion depends on mechanisms involving their own receptors and GLP-1 further requires GLUT2.
\end{abstract}

Keywords : Intestine, enteric gluco se sensor, GLP-1, GLUT2, GIP, glucose metabolism. 


\section{Introduction}

Glucagon-Like Peptide-1 (GLP-1) and the Glucose dependent Insulinotropic Polypeptide (GIP) are strong activators of glucose-induced insulin secretion (Holst and Gromada, 2004; Drucker, 1998). A major characteristic of both incretin secretion and action is a strict glucose-dependency, which confers a therapeutic advantage for incretin-based approaches for the treatment of type 2 diabetes (Zander et al., 2002). Whereas considerable evidence supports a direct pancreatic effect of these peptides for the control of glucoseinduced insulin secretion, recent data support a role for extrapancreatic GLP-1 actions, including activation of the portal glucose sensor in the control of glucose homeostasis (Balkan et al., 1999; Knauf et al., 2005; Preitner et al., 2004). Activation of the portal glucose sensor depends on the absorption of glucose from the gut, triggering of glucose sensitive cells located in the enteric/hepatoportal area. Hepatoportal glucose administration engages the central (CNS) and autonomic nervous systems (ANS) and subsequent transmission of the glucose signal, leading to improved glucose clearance and enhanced $\beta$-cell function (Adachi et al., 1984; Burcelin et al., 2000a; Stumpel et al., 1998; Stumpel, Jungermann, 1997). The CNS connected to the intestine and the endocrine pancreas via the vagus nerve controls the secretion of these hormones (Rocca, Brubaker, 1999). Hence, both the direct and indirect GLP-1-dependent routes for the control of insulin secretion could contribute to the benefical incretin effect in type 2 diabetes.

Surprisingly little is known about the molecular mechanisms of glucose-induced incretin secretion. Studies using GLUTag cells, a model of enteroendocrine L-cells showed that metabolizable carbohydrates (glucose/fructose) stimulate GLP-1 secretion by the mean of the closing of K-ATP sensitive channels (Gribble et al., 2003). This mechanism seems to be similar to the one described for the insulin secreting $\beta$-cell. Furthermore, an important regulator of both $\beta$ - cells and L intestinal cells is the ANS (Hansen et al., 2004; Rocca, 
Brubaker, 1999). We have previously shown that the glucose transporter GLUT2 and the GLP-1 receptor are key mechanisms required for glucose-dependent insulin secretion (Guillam et al., 1997; Thorens and Waeber, 1993) and for function of the hepatoportal vein glucose sensor (Burcelin et al., 2000b). To examine the importance of these same molecular mechanisms for the control of more proximal steps in the regulation of glucose-inducedincretin secretion, we characterized incretin secretion in GLUT2 and incretin receptors knockout mice. 


\section{Methods}

\section{Mice models and surgical procedures}

GLUT2 deficient mice were from our colony as previously described (Guillam et al., 1997). Briefly, GLUT2 null mice die between two and three weeks of age (Guillam et al., 1997). Transgenic reexpression of GLUT1 or GLUT2 specifically in pancreatic $\beta$ cells under the control of the rat insulin promoter (RIP) allows the mice to survive, breed, and normally secrete insulin in response to hyperglycemia. These mice were in a mixed background of C57BL/6 and SV129 and were studied at the age of 12-16 weeks (ripglut1;glut2). The GLP-1 receptor knock out mice (GLP-1R-/-) were in a mixed C57BL/6 and SV129 background and have been extensively characterized (Scrocchi et al., 1996). The GIP receptor knockout mice (GIPR -/-) were in a mixed C57BL/6 and SV129 background and have been extensively characterized (Preitner et al., 2004).

Under anesthesia (ketamine/xylazine i.p., 100 and $10 \mathrm{mg} / \mathrm{kg}$, respectively) a catheter was indwelled into the stomach as previously described (Knauf et al., 2005). Briefly, after hair shaving a $4 \mathrm{~mm}$ laparotomy was performed on the left side of the mouse at the level of the stomach. The stomach was gently extracted and a needle hole was performed on the proximal part of the stomach to introduce $5 \mathrm{~mm}$ of one extremity a teflon catheter. It was secured into the stomach by the use of surgical glue (Histoacryl, 3M Health Care, MN). The other extremity of the catheter was tunneled under the skin and exteriorized at the back of the neck. After surgery the mice were housed individually and were allowed to recover from surgery for one week. Only the mice that fully recovered their body weight were studied further. All animal experimental procedures were approved by the Rangueil Hospital Committee of the Rangueil Hospital, Toulouse, France. 


\section{Glucose tolerance test (gtt)}

The mice were fasted overnight. Three $\mathrm{g} / \mathrm{kg}$ of glucose or water $(\sim 100 \mu \mathrm{l})$ were injected over 30 seconds into the stomach catheter. For hormonal determinations, portal blood was collected after 15 minutes (considered as the time point giving the highest value of the time course (Herrmann et al., 1995)) onto a mixture of $1 \mu \mathrm{g} / \mathrm{ml}$ of aprotinin and $0.1 \mathrm{mM}$ EDTA. The portal blood was sampled as previously described (Cani et al., 2006); 250 $\mu 1$ of blood can be easily sampled using this technique. Plasma was aliquoted and kept at $-70^{\circ} \mathrm{C}$ until assayed for insulin, GLP-1, and GIP concentrations. On different sets of mice systemic blood glucose concentrations were determined before and at $0,15,30,60$, and 90 minutes after glucose or water injection using a glucose meter (Roche Diagnostic, Meylan, France).

\section{Hormonal determinations}

Plasma insulin (ELIS A kit, Mercodia, Upssala, Sweden) concentrations were determined (RIA kit, Linco Research, St Charles, USA). Intra and inter assay coefficient of variations were for both below $5 \%$ and $15 \%$, respectively. GIP and GLP-1 concentrations in plasma were measured after extraction of plasma with $70 \%$ ethanol (vol/vol, final concentration). For the GIP radioimmunoassay (Krarup et al., 1983) we used the C-terminally directed antiserum R 65, which crossreacts fully with human GIP but not with the so called GIP 8000, whose chemical nature and relationship to GIP secretion is uncertain. Human GIP and 125-I human GIP (70 MBq/nmol) were used for standards and tracer. The plasma concentrations of GLP-1 were measured (Orskov et al., 1994) against standards of synthetic GLP-1 7-36amide using antiserum code no. 89390 , which is specific for the amidated C-terminus of GLP-1 and therefore does not react with GLP-1-containing peptides from the pancreas. The results of the assay accurately reflect the rate of secretion of GLP-1 because the assay measures the sum of intact GLP-1 and the primary metabolite, GLP-1 9-36amide, into which GLP-1 is rapidly 
converted (Deacon et al., 1996). For both assays sensitivity was below $1 \mathrm{pmol} / \mathrm{l}$, intrassay coefficient of variation below $6 \%$ at $20 \mathrm{pmol} / \mathrm{l}$, and recovery of standard, added to plasma before extraction, about $100 \%$ when corrected for losses inherent in the plasma extraction procedure. Plasma GLP-1 and GIP concentrations were determined as previously described (Hansen et al., 2004). Intestinal content of incretins was determined by radioimmunoassay after extraction of intestinal biopsies (duodenum for GIP assay and ileon and colon for GLP-1 assay) by the method for small samples as described (Holst, Bersani, 1991).

\section{Statistical analysis}

Results are presented as mean \pm SE. Significant differences were analyzed by using Student's $t$-test for unpaired bilaterally distributed values of equal variance, by using GraphPad Prism version 4.00 for windows (GraphPad Software, San Diego, CA, USA; www.graphpad.com). Values were considered different when $P<0.05$. 
Results

Portal incretin concen tration during intragastric glucose tolerance test

Fifteen minutes after the glucose challenge the portal vein concentration of GLP-1 increas es more than 10 times in wild type mice (Fig ure 1A). This increase was reduced by $80 \%$ in GLP- 1 receptor and 55\% in GLUT2 and GIP receptor knockout mice. No difference in plasma GLP-1 levels was observed in the basal fasted state.

The glucose challenge also induced a ten fold increase in hepatoportal GIP concentration in wild type mice. This increase was also reduced by $40 \%$ in GLP- 1 and GIP receptor knockout mice (Figure 1B). Conversely to GLP-1, glucose-induced GIP secretion was normal in GLUT2 knockout mice suggesting that the secretion of the hormone was regulated differently compared to GLP-1 but independ ent of a GLUT2-sensitive mechan ism as described for most other glucose sensors (Burcelin et al., 2000b; Guillam et al., 1997; Leloup et al., 1998; Marty et al., 2005). Mutant mice showed glucose intolerance, as previously described (Preitner et al., 2004), (Figure 2A) which was associated with a reduced portal vein concentration of insulin (Figure 2B).

\section{Incretins intestinal content}

The impaired incretin secretion of the mutant mice could be related to a reduced intestinal content of GLP-1 or GIP. Hence, we quantified the GLP-1 and GIP intestinal content in control and mutant mice. Intestinal GLP- 1 content was reduced by $50 \%$ in GLUT2 and GIP receptor mutant mice, suggesting that the GIP and GLUT2 receptors generate signals required for optimal synthesis of intestinal GLP-1 (Figure 3A). Conversely, no differences were detected for GIP content (Figures 3B). These data could suggest that the reduced secretion of GIP in incretin receptor mutant mice is likely related to the incretin dependency of the secretory system rather than to a reduced intestinal content of the hormone. 


\section{Discussion}

The present data show that the incretin receptors are both required for the regulation of oral glucose-induced GLP-1 and GIP secretions and that GLUT2 is also required for GLP-1 secretion. As opposed to GIP, GLP-1 synthesis requires GIP and GLUT2 receptors.

Therapeutic strategies enhancing glucose-stimulated incretin secretion might be useful for the treatment of diabetes as these hormones are released at the vicinity of their most proximal physiological target, the enteric glucose sen sor. Type 2 diabetes is characterized by a lower plasma GLP-1 release after a glucose load, one strategy could consist in stimulating endogenous incretin secretion (Vilsboll et al., 2003). Recently, we have shown that a four week treatment with dietary fibres attenuated the development of high-fat diet-induced diabetes (Cani et al., 2006) by a mechanism requiring the GLP-1 receptor. We conclude that GLP-1 secretion into the portal vein area was important to mediate the hormonal effect. The systemic injection of GLP-1 as a therapeutic strategy does not increase portal GLP-1 concentration and cannot activate the hepatoportal glucose sensors (Burcelin et al., 2001). Conversely, DPPIV-inhibitors can increase the GLP-1 portal concentration, activate the GLP1 receptor and consequently engage the hepatoportal system.

We show that, in absence of at least one of the incretin receptors, secretion of both incretins is impaired in response to an oral glucose challenge. This data suggests the existence of an autoregulatory loop enhancing the secretion of the incretin themselves (Figure 4). We further demonstrate that impaired GLP-1 secretion in GLP-1 receptor knockout mice was not related to reduced-intestinal hormone content. These findings indicate that the GLP-1 receptor is required for normal glucose-dependent control of GLP-1 secretion. It has been shown that GLP-1 secretion is dependent on the integrity of the enteric parasympathetic branch of the autonomous nervous system and inhibited by the sympathetic nervous system (Hansen et al., 2004). In our model, glucose increases portal GLP-1 concentrations by 10 times in wild type 
mice. This increase was reduced by $80 \%$ in GLP- 1 and 55\% in GLUT2 and GIP receptors knockout, suggesting that GLP-1, GIP and GLUT2 receptors are required for the secretion of incretins by the mean of a nervous signaling pathway and the ANS. Reinforcing this hypothes is is the fact that vagotomy prevents GLP-1 secretion (Rocca and Brubaker, 1999). Our data also implicates a role for the glucose transporter GLUT2 in the control of GLP-1 secretion. GLUT-2 is expressed in the CNS (Leloup et al., 1994) and required for ANSmediated hepatoportal glucose sensing (Burcelin et al., 2000b). However, glucose enters the epithelial cell through the sodium-glucose cotransporter SGLT-1 (Turk et al., 1991) and is released into the mesenteric blood through GLUT2. We could suggest that the GLUT2dependent enteric glucose absorption is not a major regulatory mechanism for enteric glucose sensing. A complementary set of evidence has also suggested that carbohydrate receptors exist in the lumen of the intestine (Dyer et al., 2003a; Dyer et al., 2003b; Dyer et al., 2005). Interestingly, the intestinal GLP-1 content was reduced in GLUT2 and GIP receptor KO but not in GLP-1 receptor KO mice. This shows the importance of these molecular mechanisms for the regulation of GLP-1 synthesis which could contribute in part to the impaired secretion of the hormone. Conversely, GIP secretion in response to glucose did not require GLUT2 but did involve both incretin receptors. These impairments were not simply attributable to reduced intestinal stores of GIP since intestinal GIP content was normal in mutant mice. Other authors have previously shown that GLP-1 receptors knock out mice exhibited an exacerbate GIP secretion in response to an oral glucose load (Pederson et al., 1998). The involvement of the ANS in the regulation of GIP secretion has not been demonstrated, suggesting a direct effect of glucose on $\mathrm{K}$ cells. The majority of $\mathrm{K}$ cells are located in the duodenum where glucose is absorbed and could be in direct contact with glucose for the stimulation of GIP release. Again, this mechanism does not involve GLUT2 as this transporter is not an obligatory mechanism for transepithelial glucose transport and GIP 
secretion was normal in GLUT2 mutant mice (Stumpel and Jungermann, 1997). The regulatory roles of GIP and GLP-1 receptors on GIP secretion cannot be fully explained by our present data but suggest that one or more cell types, required for transduction of an enteral glucose signal, are defective in incretin receptor knock out mice. The decrease in GLP-1 content of GLUT2 and GIP receptor knock out mice could also be attributed to modification in L-cell number, structure and/or differentiation. Reinforcing this hypothesis, we have recently demonstrated that the increase in colonic GLP-1 content was associated to a higher L-cells differentiation and total cell number (Cani et al., 2007). Diabetes is characterized by a state of glucose unresponsiveness. Therefore, another possible explanation, responsible for the altered GLP-1 secretion in response to oral glucose load in the knock out mice, would be the impairment of the enteric glucose sensing system in the GLUT2 and GLP-1 receptor knock out mice.

In conclusion, our study provides new insights into the molecular mechanisms controlling glucose-dependent incretin secretion. Our data illustrates a previously unappreciated essential role for GLP-1 and GIP receptors in the control of incretin secretion while GLUT2 is only required for the secretion of GLP-1. Strategies which aim to enhance intestinal glucose sensing might help to stimulate the physiological release of incretin hormones, thereby providing a valuable adjunctive approach for the treatment of type 2 diabetes.

\section{Acknowledgments}

RB, CK and PDC are members of CESNA (Club d'Etude du Système Nerveux Autonome) and are grateful for its financial support. $\mathrm{CK}$ was in part by operating grant from ALFEDIAM/NOVARTIS and from l'Association pour la Recherche sur le Diabète dans le 
cadre du Programme National de Recherche sur le Diabète, France. DJD was supported in part by operating grants from the Canadian Diabetes Association and the Juvenile Diabetes Research Foundation and by the Canada Chairs Program. PDC and NMD were supported in part by grants from the FNRS and FSR from the Univeriste catholique de Louvain. This work was supported by a grant from the Swiss National Science Foundation (3100-065219-01) to BT. PDC is Postdoctoral Researcher from the FNRS (Fonds de la Recherche Scientifique, Brussels, Belgium).

\section{References}

Adachi,A., Shimizu,N., Oomura,Y., Kobashi,M., 1984. Convergence of hepatoportal glu cosesensitive afferent signals to glucose-sensitive units within the nucleus of the solitary tract. Neurosci.Lett. 46, 215-218.

Balkan,B., Kwasnik,L., Miserendino,R., Holst,J.J., Li,X., 1999. Inhibition of dipeptidyl peptidase IV with NVP-DPP728 increases plasma GLP-1 (7-36 amide) concentrations and improves oral glucose tolerance in obese Zucker rats. Diabetologia 42, 1324-1331.

Burcelin,R., Da Costa,A., Drucker,D., Thorens,B., 2001. Glucose competence of the hepatoportal vein sensor requires the presence of an activated glucagon-like peptide-1 receptor. Diabetes 50, 1720-1728.

Burcelin,R., Dolci,W., Thorens,B., 2000a. Portal glucose infusion in the mouse induces hypoglycemia: evidence that the hepatoportal glucose sensor stimulates glucose utilization. Diabetes 49, 1635-1642.

Burcelin,R., Dolci,W., Thorens,B., 2000b. Glucose sensing by the hepatoportal sensor is GLUT2-dependent: in vivo analysis in GLUT2-null mice. Diabetes 49, 1643-1648. 
Cani,P.D., Hoste,S., Guiot,Y., Delzenne,N.M., 2007. Dietary non-digestible carbohydrates promote L-cell differentiation in the proximal colon of rats. Br.J.Nutr., Mars 19 1-6 Epub ahead.

Cani,P.D., Knauf,C., Iglesias,M.A., Drucker,D.J., Delzenne,N.M., Burcelin,R., 2006. Improvement of glucose tolerance and hepatic insulin sensitivity by oligofructose requires a functional glucagon-like Peptide 1 receptor. Diabetes 55, 1484-1490.

Deacon,C.F., Pridal,L., Klarskov,L., Olesen,M., Holst,J.J., 1996. Glucagon-like peptide 1 undergoes differential tissue-specific metabolism in the anesthetized pig. Am.J.Physiol 271, E458-E464.

Drucker,D.J., 1998. Glucagon-like peptides. Diabetes 47, 159-169.

Dyer,J., Salmon,K.S., Zibrik,L., Shirazi-Beechey,S.P., 2005. Expression of sweet taste receptors of the T1R family in the intestinal tract and enteroendocrine cells. Biochem.Soc.Trans. 33, 302-305.

Dyer,J., Vayro,S., King,T.P., Shirazi-Beechey,S.P., 2003a. Glucose sensing in the intestinal ep ithelium. Eur.J.Biochem. 270, 3377-3388.

Dyer,J., Vayro,S., Shirazi-Beechey,S.P., 2003b. Mechanism of glucose sensing in the small intestine. Biochem.Soc.Trans. 31, 1140-1142.

Guillam,M.T., Hummler,E., Schaerer,E., Yeh,J.I., Birnbaum,M.J., Beermann,F. et al., 1997. Early diabetes and abnormal postnatal pancreatic islet development in mice lacking Glut-2. Nat.Genet. 17, 327-330. 
Gribble,F.M., Williams,L., Simpson,A.K., Reimann,F., 2003. A novel glucose-sensing mechanism contributing to glucagon-like peptide- 1 secretion from the GLUTag cell line. Diabetes 52, 1147-1154.

Hansen,L., Lampert,S., Mineo,H., Holst,J.J., 2004. Neural regulation of glucagon-like peptide-1 secretion in pigs. Am.J.Physiol Endocrinol.Metab 287, E939-E947.

Herrmann,C., Goke,R., Richter,G., Fehmann,H.C., Arnold,R., Goke,B., 1995. Glucagon-like peptide-1 and glucose-dependent insulin-releasing polypeptide plasma levels in response to nutrients. Digestion 56, 117-126.

Holst,J., and Bersani,M. (1991) Assays for peptide products of somatostatin gene expression. In Methods in Neurosciences. San Diego: Academic Press, pp. 3-22.

Holst,J.J., Gromada,J., 2004. Role of incretin hormones in the regulation of insulin secretion in diabetic and nondiabetic humans. Am.J.Physiol Endocrinol.Metab 287, E199-E206.

Knauf,C., Cani,P.D., Perrin,C., Iglesias,M.A., Maury,J.F., Bernard,E. et al., 2005. Brain glucagon-like peptide-1 increases insulin secretion and muscle insulin resistance to favor hepatic glycogen storage. J.Clin.Invest 115, 3554-3563.

Krarup,T., Madsbad,S., Moody,A.J., Regeur,L., Faber,O.K., Holst,J.J., Sestoft,L., 1983. Diminished immunoreactive gastric inhibitory polypeptide response to a meal in newly diagnosed type I (insulin-dependent) diabetics. J.Clin.Endo crinol.Metab 56, 1306-1312.

Leloup,C., Arluison,M., Lepetit,N., Cartier,N., Marfaing-Jallat,P., Ferre,P., Penicaud,L., 1994. Glucose transporter 2 (GLUT 2): expression in specific brain nuclei. Brain Res. 638, $221-226$. 
Leloup,C., Orosco,M., Serradas,P., Nicolaid is,S., Penicaud,L., 1998. Specific inhibition of GLUT2 in arcuate nucleus by antisense oligonucleotides suppress es nervous control of insulin secretion. Brain Res.Mol.Brain Res. 57, 275-280.

Marty,N., Dallaporta,M., Foretz,M., Emery,M., Tarussio,D., Bady,I. et al., 2005. Regulation of glucagon secretion by glucose transporter type 2 (glut2) and astrocyte-dependent glucose sensors. J.Clin.Invest 115, 3545-3553.

Orskov,C., Rabenhoj,L., Wettergren,A., Kofod,H., Holst,J.J., 1994. Tissue and plasma concentrations of amidated and glycine-extended glucagon-like peptide I in humans. Diabetes $43,535-539$

Pederson,R.A., Satkunarajah,M., McIntosh,C.H.S., Scrocchi,L.A., Flamez,D., Schuit,F. et al., 1998. Enhanced glucose-dependent insulinotropic polypeptide secretion and insulinotropic action in glucagon-like peptide 1 receptor (-/-) mice. Diabetes 47, 1046-1052.

Preitner,F., Ibberson,M., Franklin,I., Binnert,C., Pende,M., Gjinovci,A. et al., 2004. Glucoincretins control insulin secretion at multiple levels as revealed in mice lacking GLP-1 and GIP receptors. J.Clin .Invest 113, 635-645.

Rocca,A.S., Brubaker,P.L., 1999. Role of the vagus nerve in mediating proximal nutrientinduced glucagon-like peptide-1 secretion. Endocrinology 140, 1687-1694.

Scrocchi,L.A., Brown,T.J., MaClusky,N., Brubaker,P.L., Auerbach,A.B., Joyner,A.L., Drucker,D.J., 1996. Glucose intolerance but normal satiety in mice with a null mutation in the glucagon-like peptide 1 receptor gene. Nat.Med 2, 1254-1258. 
Stumpel,F., Jungermann,K., 1997. Sensing by intrahepatic muscarinic nerves of a portalarterial glucose concentration gradient as a signal for insulin-dependent glucose uptake in the perfused rat liver. FEBS Lett. 406, 119-122.

Stumpel,F., Scholtka,B., Jungermann,K., 1998. Impaired glucose sensing by intrahepatic, muscarinic nerves for an insulin-stimulated hepatic glucose uptake in streptozotocin-diabetic rats. FEBS Lett. 436, 185-188.

Thorens,B., Waeber,G., 1993. Glucagon-like peptide-I and the control of insulin secretion in the normal state and in NIDDM. Diabetes 42, 1219-1225.

Turk,E., Zabel,B., Mundlos,S., Dyer,J., Wright,E.M., 1991. Glucose/galactose malabsorption caused by a defect in the $\mathrm{Na}+$ /glucose cotransporter. Nature $350,354-356$.

Vilsboll,T., Krarup,T., Sonne,J., Madsbad,S., Volund,A., Juul,A.G., Holst,J.J., 2003. Incretin secretion in relation to meal size and body weight in healthy subjects and people with type 1 and type 2 diabetes mellitus. J.Clin.Endocrinol.Metab 88, 2706-2713.

Zander,M., Madsbad,S., Madsen,J.L., Holst,J.J., 2002. Effect of 6-week course of glucagonlike peptide 1 on glycaemic control, insulin sensitivity, and beta-cell function in type 2 diabetes: a parallel-group study. Lancet 359, 824-830. 

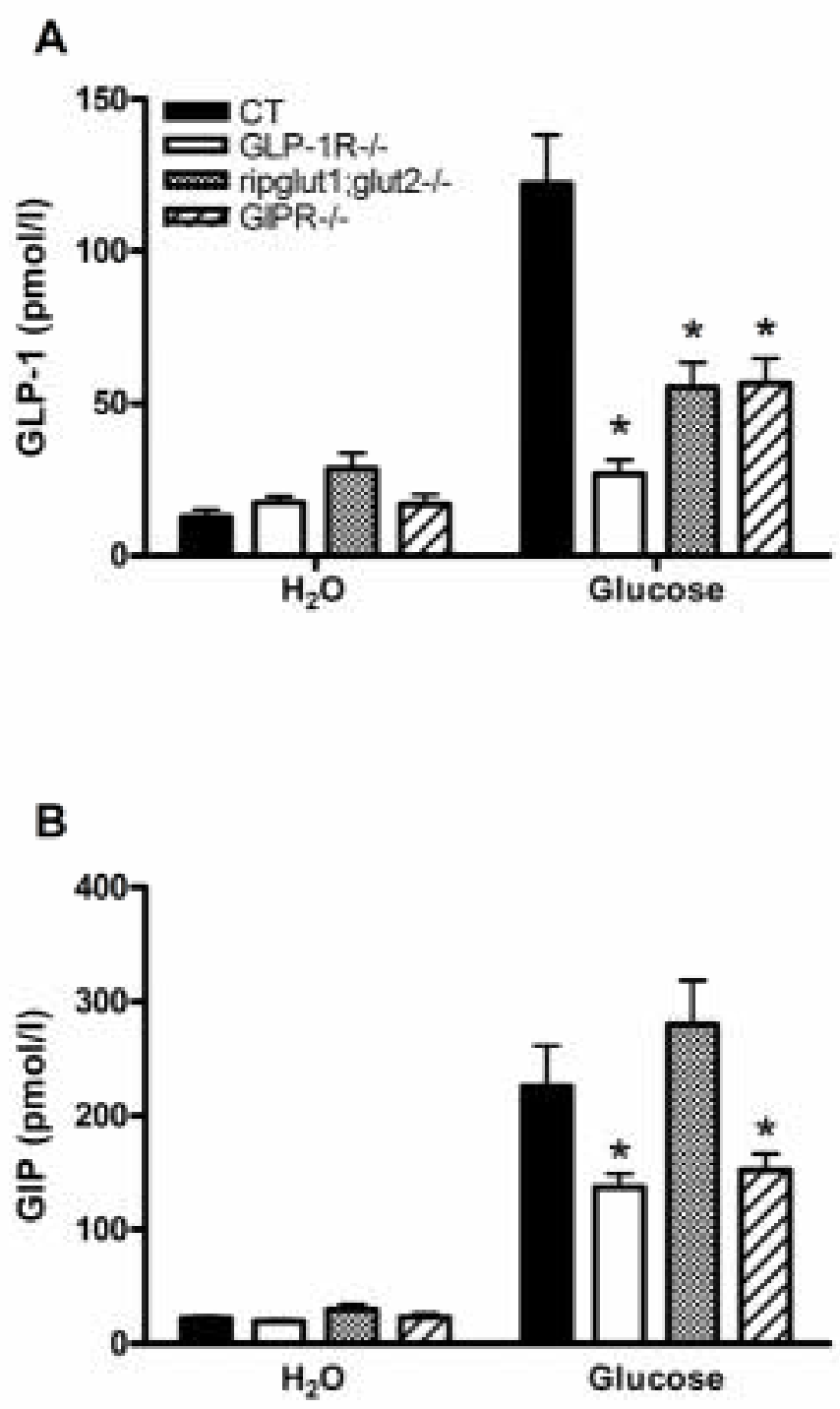

Figure 1: Incretin secretion is reduced in GLUT2, GLP-1 and GIP receptors knockout mice.

A) Plasma GLP-1 and B) GIP concentrations (pmol/l) in the hepatoportal vein of wild type (CT), GLP-1 receptor knockout (GLP-1 R-/-) GLUT2 knockout (ripglut1;glut2 -/-), and GIP receptor knockout (GIPR-/-) mice fifteen minutes after an intragastric glucose or water $\left(\mathrm{H}_{2} \mathrm{O}\right)$ challenge. *, Statistically significant from wild type mice when $P<0.05$. Eight to ten mice per group have been studied. 


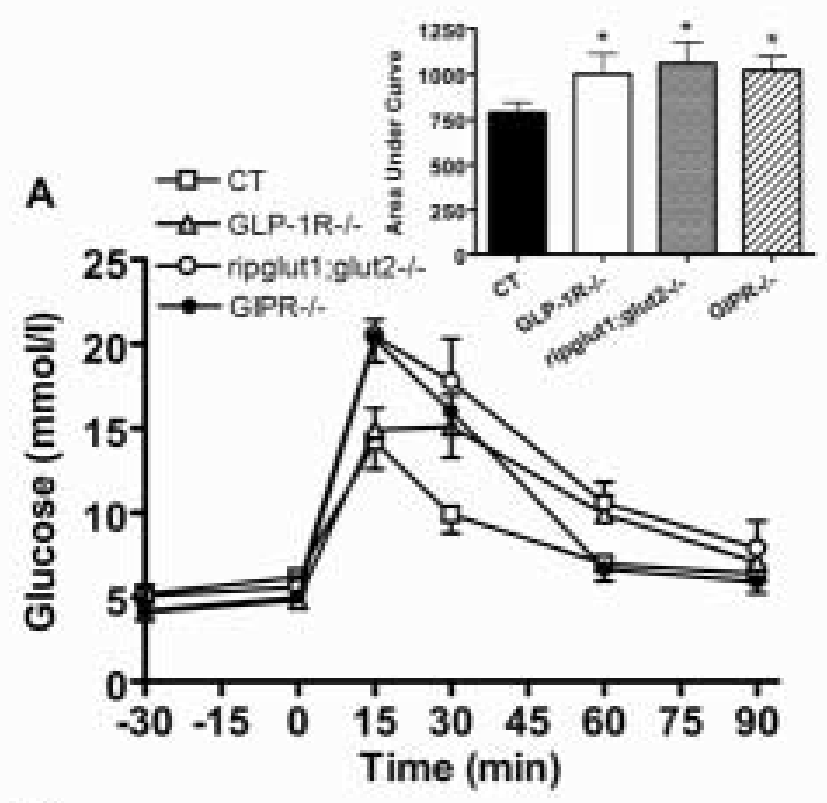

B

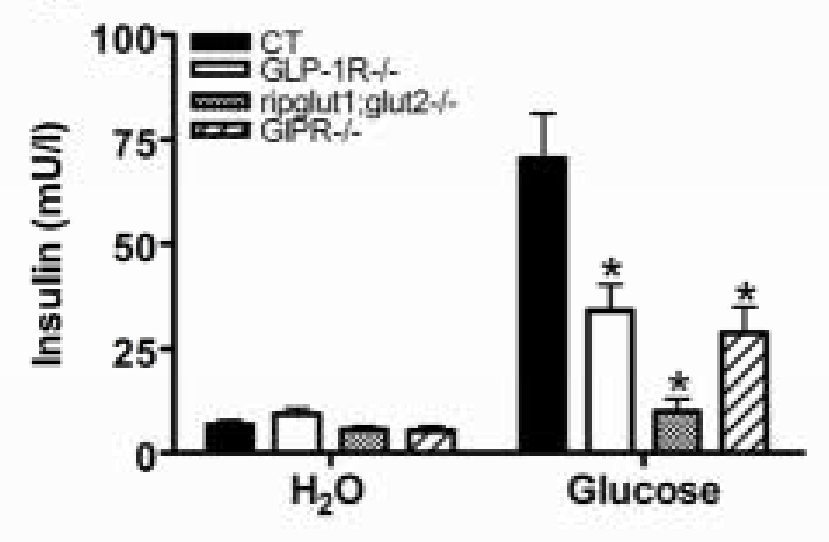

Figure 2: Glucose intolerance and impaired insulin secretion in GLUT2, GLP-1 and GIP receptors knockout mice.

A) Glucose concentration ( $\mathrm{mmol} / \mathrm{l})$ in the systemic blood following an oral glucose or water $\left(\mathrm{H}_{2} \mathrm{O}\right)$ challenge and $\left.\mathbf{B}\right)$ insulin levels $(\mathrm{mU} / \mathrm{l})$ fifteen minutes after an oral glucose or water challenge in the hepatoportal vein of wild type (CT), GLP-1 receptor knockout (GLP-1 R-/-) GLUT2 knockout (ripglut1;glut2 -/-), and GIP receptor knockout (GIPR-/-) mice. *, Statistically significant from wild type mice when $P<0.05$. Eight to ten mice per group have been studied. 

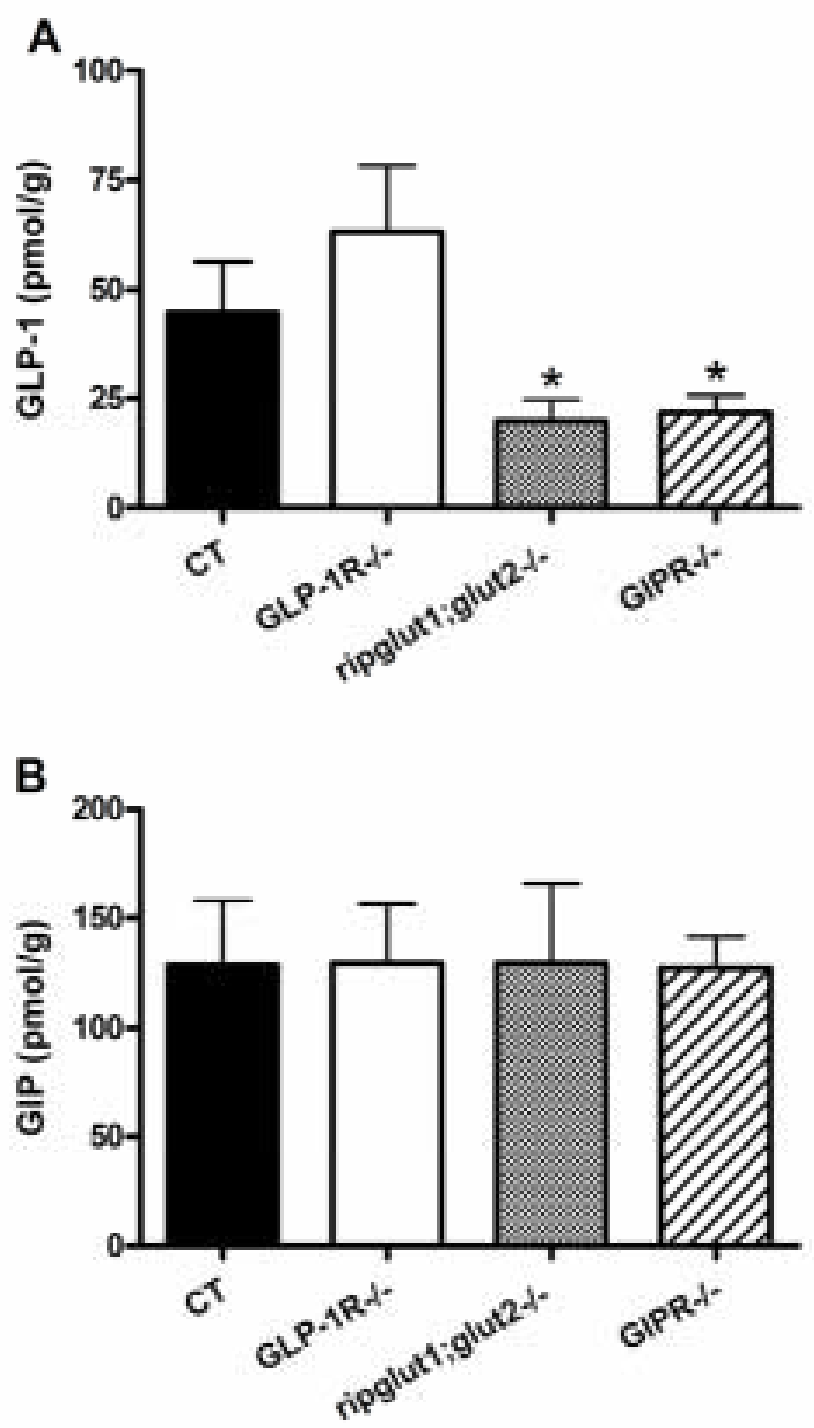

Figure 3: Intestinal GLP-1 and GIP content in mutant mice

A) Intestinal GLP-1 and B) GIP concentration s (pmol/g of tissue) in wild type (CT), GLP-1 receptor knockout (GLP-1 R-/-), GLUT2 knockout (ripglut1;glut2 -/-), and GIP receptor knockout (GIPR-/-) mice. *, Statistically sign ificant from wild type mice when $P<0.05$. Eight to ten mice per group have been studied. 


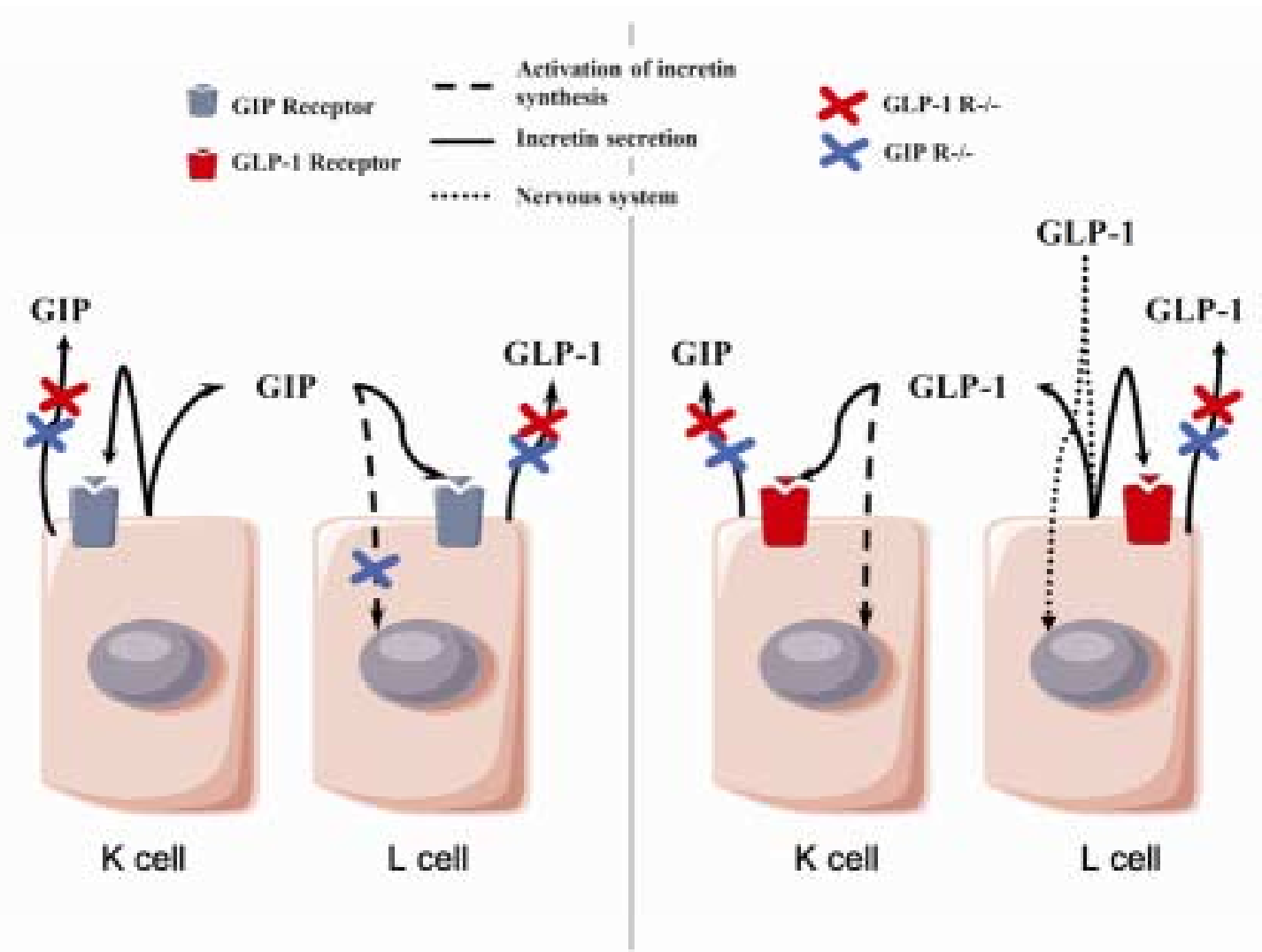

Figure 4: Summary of the intestinal GLP-1 and GIP synthes is and secretion.

Left panel describes the regulation of GLP-1 secretion and synthesis by GIP as well as GIP secretion by GIP. Right panel describes the regulation of incretin secretion and synthesis by GLP-1. In response to an oral gluco se load the secretion of GIP and GLP-1 is impaired in mice lacking incretin receptors. We suggest that exist an autoregulatory loop where incretin themselves would enhance their secretion. In addition, the autocrine and paracrine effects of the GLP-1 on incretin secretion (plain lines) would recruit the nervous system (dotted line). 